MATEC Web of Conferences 6, 02006 (2013)

DOI: $10.1051 /$ matecconf/20130602006

(C) Owned by the authors, published by EDP Sciences, 2013

\title{
Preventive effect on spalling of UFC using jute fiber at high temperature
}

\author{
M. Ozawa ${ }^{1}$, Z. Bo ${ }^{2}$, J. Kawaguchi ${ }^{2}$ and Y. Uchida ${ }^{3}$ \\ 1 Division of Environmental Engineering Science, Gunma University, Kiryu City, Japan \\ 2 Graduate shcool of Engineering, Gifu University, Gifu City, Japan \\ 3 Information and Multimedia Center, Gifu University, Gifu City, Japan
}

\begin{abstract}
In this study, we examined the relationship between spalling behaviour and spalling ratio of UFC with three kinds of short fibers (jute, polypropylene, water-soluble polyvinyl alcohol) at high temperature. The heating temperatures were $400{ }^{\circ} \mathrm{C}$ and $600^{\circ} \mathrm{C}$. Although the specimen with jute fiber dosage of $0.19 \%$ by volume was occurred explosive spalling, the damage of specimen was slightly small. It appears that the addition of jute fiber to UFC is effective for preventing spalling.
\end{abstract}

\section{INTRODUCTION}

Ultra-high strength fiber reinforced concrete (UFC) [1] using steel fiber is a material with specifically advantageous characteristics, resulting in excellent mechanical properties and a very low permeability. Its high strength ( $>200 \mathrm{MPa}$ in compression and $>30 \mathrm{MPa}$ in bending) makes it resistant to severe loading and environmental action. Its dense matrix, leads to the very low permeability, which can improve the durability of UFC members compared to conventional concrete members. Previous studies have clearly shown the advantages to using UFC [2, 3]. However, UFC has been particularly susceptible to spalling in fire. Generally, the addition of synthetic fibers, especially polypropylene (PP) fiber to highstrength concrete is widely used as an effective measure to prevent explosive spalling [4-6]. Authors have investigated the effectiveness of adding jute fiber (natural fiber) to UFC (fc; $150 \mathrm{MPa}$ with aramid fiber), for preventing spalling at high temperature [7]. However, it should be noted the effectiveness of adding jute fiber to higher strength UFC for preventing spalling at high temperature. In this study, we examined the relationship between spalling behaviour and spalling ratio of UFC (fc:200MPa) with three kinds of short fibers (jute, PP, water-soluble polyvinyl alcohol) at high temperature. The heating temperatures were $400^{\circ} \mathrm{C}$ and $600^{\circ} \mathrm{C}$.

\section{OUTLINE OF THE EXPERIMENT}

\subsection{Mixture proportion}

Table 1 gives the mix proportions of the mortar matrix used in this study. Pre-mixed cement with silica fume was used. The UFC mix relies on achieving optimum particle packing and reactive powders to develop many of its extraordinary features. The basic premise behind particle packing is to increase the density of the concrete and develop a uniform microstructure by filling the voids around the cement particles.

This is an Open Access article distributed under the terms of the Creative Commons Attribution License 2.0, which permits unrestricted use, distribution, and reproduction in any medium, provided the original work is properly cited. 
MATEC Web of Conferences

Table 1. Mix.

\begin{tabular}{|c|c|c|c|c|}
\hline \multicolumn{5}{|c|}{ Unit weight $\left(\mathrm{kg} / \mathrm{m}^{3}\right)$} \\
\hline Premixed cement & Fine aggregate & Water & Water reducing agent & Steel fiber \\
\hline 1322 & 932 & 180 & 24 & 157 \\
\hline
\end{tabular}

Table 2. Fibers.

\begin{tabular}{|c|c|c|c|c|c|}
\hline \multirow{2}{*}{ Type of fiber } & Length & Diameter & Melting point & Density & \multirow{2}{*}{ note } \\
\cline { 2 - 5 } & $\mathrm{mm}$ & $\mu \mathrm{m}$ & ${ }^{\circ} \mathrm{C}$ & $\mathrm{g} / \mathrm{cm}^{3}$ & \\
\hline Jute & 12 & $10 \sim 30$ & - & $1.3-1.45$ & Carbonization \\
\hline WSPVA & 4,12 & 12 & $220-240$ & 1.3 & Water solving \\
\hline PP & 12 & 42 & 170 & 0.91 & Melting \\
\hline
\end{tabular}

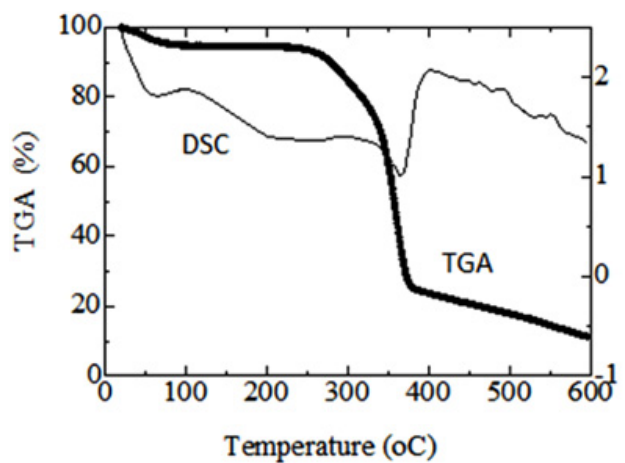

Figure 1. DSC-TGA results (Jute).

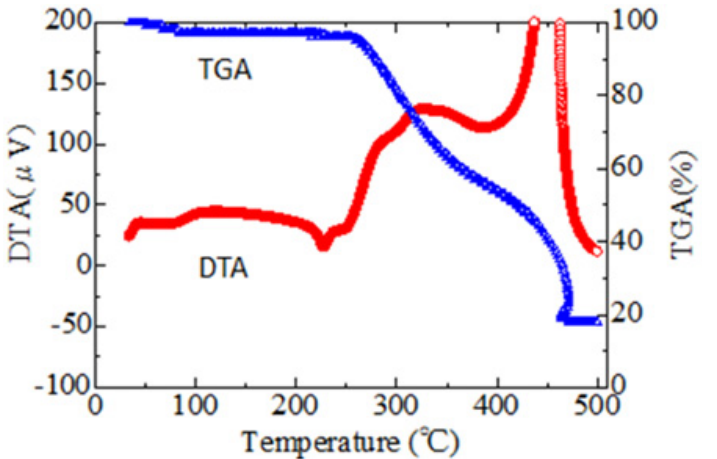

Figure 2. DTA-TGA results (WSPVA).

\subsection{Properties of Fibers}

The steel fibers used in this study had a diameter of $0.2 \mathrm{~mm}$ and a length of $15 \mathrm{~mm}$. Table 2 shows the properties of the natural jute fibers and the synthetic WSPVA and PP fibers used (jute fiber addition ratio: 0.19 vol\%; length: $12 \mathrm{~mm}$; WSPVA fiber addition ratio: 0.19 vol\%; length: $4 \mathrm{~mm}$ and $12 \mathrm{~mm}$; PP fiber addition ratio: 0.19 vol\% and 1.0vol\%; length: $12 \mathrm{~mm}$ ) [7]. Photos 1 (obtained with a scanning electron microscope (SEM)) show the straw-like structure of the jute fibers. WSPVA fibers have a lower dissolving point $\left(50^{\circ} \mathrm{C}\right.$ to $\left.90^{\circ} \mathrm{C}\right)$ than other synthetic types, and also have a lower melting point. These properties have been used for more than 30 years in Japan to improve the permeability of concrete and thereby reduce the likelihood of explosion in castable refractories.

Figure 1 shows the results of thermal analysis of jute fiber using differential scanning calorimetry (DSC) and thermogravimetric analysis (TGA). The exothermic peak (which represents the amount of heat released from the sample) of the DSC curve for such fibers was observed at a maximum temperature of $360{ }^{\circ} \mathrm{C}$. The TGA curve initially exhibits a slight decrease in weight at temperatures below $100{ }^{\circ} \mathrm{C}$ due to moisture loss, but both curves begin to show de-composure at $265^{\circ} \mathrm{C}$ and $340^{\circ} \mathrm{C}$. The decomposition temperature for the jute fiber sample at $80 \%$ weight loss was $390^{\circ} \mathrm{C}$. Figure 2 shows the DSC and TGA results for PP fibers, whose melting, vaporization and burning points were $173{ }^{\circ} \mathrm{C}, 341{ }^{\circ} \mathrm{C}$ and $447^{\circ} \mathrm{C}$, respectively. Higher temperatures reduce their viscosity via the two mechanisms of increased molecular energy and reduced molecular size caused by thermal degradation. Figure 3 shows the DSC and TGA results for WSPVA fibers, whose melting, vaporization and burning points were $227^{\circ} \mathrm{C}, 246^{\circ} \mathrm{C}$ and $470{ }^{\circ} \mathrm{C}$, respectively. 


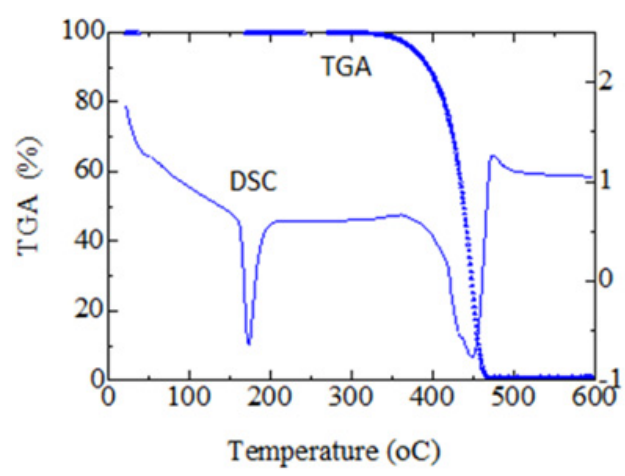

Figure 3. DSC-TGA results (PP).

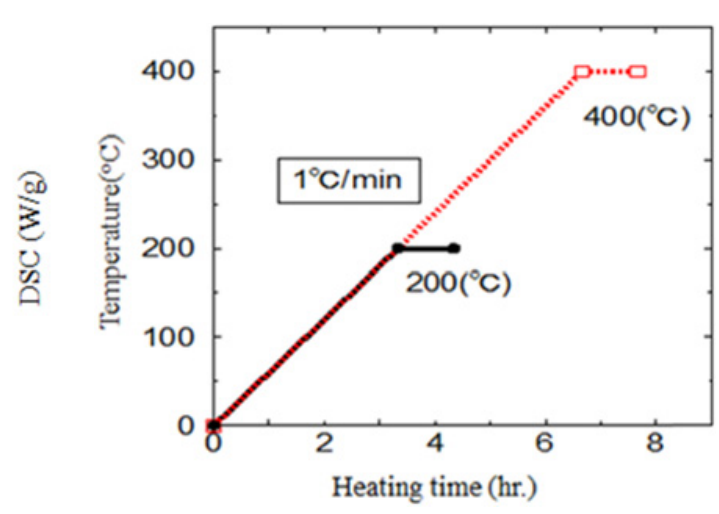

Figure 4. Heating history (Strength test).

\subsection{Mixing and flow test}

The mortar components were placed into a 10-liter Hobart mixer and agitated. Mixing process is belows:

1) Add pre-mixed cement, pre-mixed sand, mix for 1 minutes.

2) Add water and super plasticizer, mix for 2 minutes, scrape bowl and mix for 5 minutes.

3) Add steel fiber and other fibers mix for 4 minutes.

The flowability of the mortar was evaluated in a flow test using a cone mold with dimensions of $70 \mathrm{~mm}$ (top diameter) $\times 100 \mathrm{~mm}$ (bottom diameter) $\times 60 \mathrm{~mm}$ (height). Joggings were not included in the flow test.

\subsection{Specimen fabrication and curing}

Heating test specimens with $50 \mathrm{~mm}$ in diameter and $100 \mathrm{~mm}$ in height were used for this study. The concrete was placed in molds and compacted using a table vibrator. The surfaces of the specimens were plastic-wrapped immediately after placement and left for two days in a curing room at $20^{\circ} \mathrm{C}$. After demolding, steam curing was carried out for two days at a temperature of $90^{\circ} \mathrm{C}$.

\subsection{Heating tests}

Specimens were heated in a muffle furnace with an operating temperature range of $100^{\circ} \mathrm{C}$ to $1,150^{\circ} \mathrm{C}$. The unit used was a $2.5 \mathrm{~kW}$ iron-chrome wire heater with a $220 \mathrm{~V}$ power source.

Figure 4 shows the spalling test's heating times and temperatures, which were $400^{\circ} \mathrm{C}$ and 30 minutes, $600^{\circ} \mathrm{C}$ and 20 minutes. After being heated, the specimens were allowed to cool naturally. Figure 5 shows pre-heating after the compressive strength tests. The heating temperatures were $200{ }^{\circ} \mathrm{C}$ and $400^{\circ} \mathrm{C}$. Heating speed was $1^{\circ} \mathrm{C} / \mathrm{min}$. After being heated, the specimens were allowed to cool naturally.

\section{RESULTS AND DISCUSSION}

\subsection{Flowability}

Figure 6 gives the flow test results. The flow value of each mixture was Control: $293 \mathrm{~mm}, \mathrm{~J}-0.19$ : $265 \mathrm{~mm}$, P-0.19: $280 \mathrm{~mm}, \mathrm{P}-1.0: 135 \mathrm{~mm}$, WS-4: $253 \mathrm{~mm}$ and WS-12: $211 \mathrm{~mm}$. The flow value of Control mixture without fiber was $293 \mathrm{~mm}$, which was in the target range, but the high contents of 


\section{MATEC Web of Conferences}

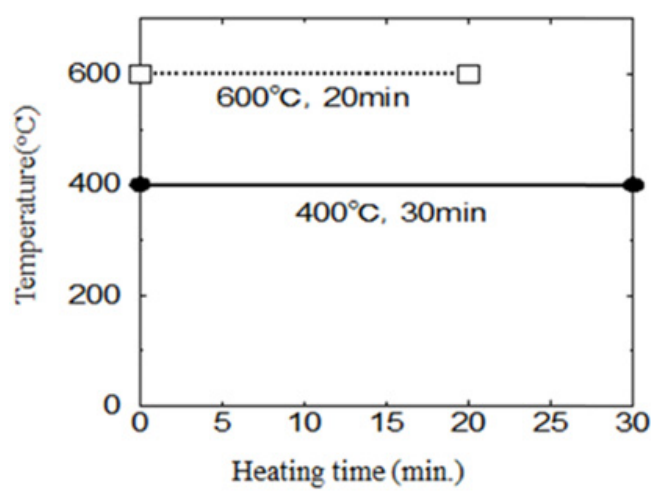

Figure 5. Heating history (spalling test).

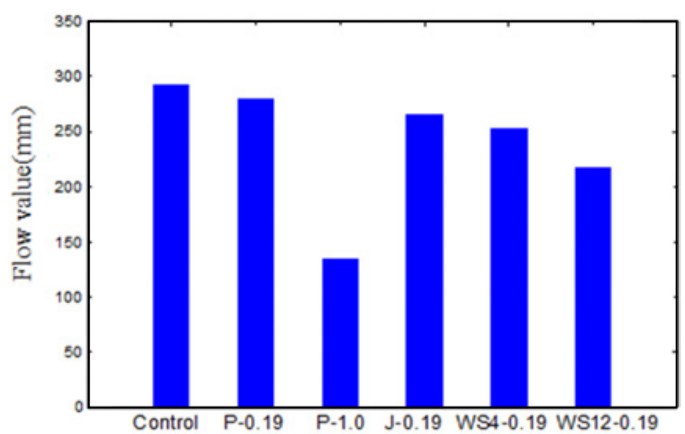

Figure 6. Flow test results.

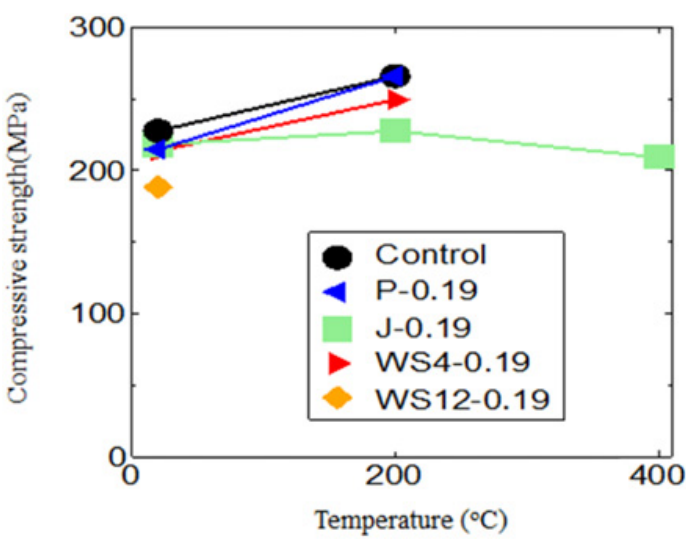

Figure 7. Compressive strength.

fiber notably decreased the flow. Especially, the mixture P- 1.0 had the highest loss of the flow, while the other mixtures with fibers showed relatively better performance.

\subsection{Mechanical properties}

Figures 7 shows the compressive strength of harden UFC of Control, P-0.19, J-0.19, WS4-0.19, WS120.19 , respectively. The compressive strength of Control specimen without fiber was $228 \mathrm{MPa}$, which was in the target range. Their results indicate values ranging from $188 \mathrm{MPa}$ to $228 \mathrm{MPa}$ for the specimens before heating test. After heating at $200{ }^{\circ} \mathrm{C}$, their strengths became ranging from $227 \mathrm{MPa}$ to $266 \mathrm{MPa}$ without WS12-0.19. It was clear that strength increased in Conrol, P-0.19, J-0.19, WS4-0.19 specimens. Regarding the improved strength after heating at $200{ }^{\circ} \mathrm{C}$, it was consider to occur additional hydration of cement. After heating at $400{ }^{\circ} \mathrm{C}$, the strength of J-0.19 specimen was $209 \mathrm{MPa}$.

The strengths could not be measured for other specimens after heating at $400{ }^{\circ} \mathrm{C}$, because these specimens were occured to explosive spalling.

\subsection{Extent of spalling}

Figure 8 shows the extent of spalling in all specimens after the fire tests. Control specimens were more severely damaged at the temperature $400{ }^{\circ} \mathrm{C}$. In the case of specimens with added fibers, it was clear that 
Table 3. Extent of spalling.

\begin{tabular}{|c|c|c|c|}
\hline & \multicolumn{3}{|c|}{ Heating Temperature $\left({ }^{\circ} \mathrm{C}\right)$} \\
\hline Type of Specimens & & & \\
\hline & & & \\
\hline
\end{tabular}

the spalling tendency decreased. With a heating temperature of $400{ }^{\circ} \mathrm{C}$ and a heating time of 30 minutes, explosive spalling was observed in Control, P-0.19, WS4-0.19, and WS12-0.19 specimens, but not in the J-0.19 specimen. The extent of spalling in the WS4-0.19 and WS12-0.19 specimens was small. With a heating temperature of $600^{\circ} \mathrm{C}$ and a heating time of 20 minutes, explosive spalling was observed in all specimens. P-1.0 and WS12-0.19 specimens were severely damaged, while the extent of spalling in the $\mathrm{J}-0.19$ specimens was small. It appears that the addition of jute fiber to UFC is effective for preventing spalling.

\section{CONCLUSION}

The results obtained by the experiment can be summarized as follows:

1) Control mixture without fiber addition indicated $293 \mathrm{~mm}$ in flow value, which was in the target range, but the high contents of fiber notably decreased the flow. Especially, the mixture containing P- 1.0 had the highest loss of the flow, while the others with fibers showed relatively better performance. 


\section{MATEC Web of Conferences}

2) Control specimen without fiber addition indicated $228 \mathrm{MPa}$ in the compressive strength, which was in the target range. The compressive strengths were ranging from $188 \mathrm{MPa}$ to $228 \mathrm{MPa}$ for the specimens before heating test. Regarding the improved strength after heating at $200{ }^{\circ} \mathrm{C}$, it was consider to occur additional hydration of cement.

3) For the specimens with added fibers, it was clear that the spalling tendency decreased. With a heating temperature of $400{ }^{\circ} \mathrm{C}$ and a heating time of 30 minutes, explosive spalling was observed in Control, P-0.19, WS4-0.19, and WS12-0.19 specimens, but not in the J-0.19 specimen.

4) With a heating temperature of $600^{\circ} \mathrm{C}$ and a heating time of 20 minutes, explosive spalling was observed in all specimens. P-1.0 and WS12-0.19 specimens were severely damaged, while the extent of spalling in the J-0.19 specimens was small. It appears that the addition of jute fiber to UFC is effective for preventing spalling.

This study was supported by the Grant-in-Aid for Scientific Research C (General) of the Japan Society for the Promotion of Science 2010, No. 22560461 (Head: Dr. M. Ozawa).

The authors would like to express their gratitude to the organization for its financial support, and also wish to thank Tesac Co., Ltd., Kuraray Co., Ltd. and Teijin Co., Ltd. for their assistance in this study.

\section{References}

[1] JSCE, "Recommendations for Design and Construction of Ultra High Strength Fiber Reinforced Concrete Structures," 2006.

[2] Kawaguchi T. et al., "Mechanical Properties of Flexural Members Using Ultra High Strength Fiber Reinforced Concrete," Proceedings of the 8th International Symposium on Utilization of HighStrength and High-Performance Concrete, (2): JCI, JPCEA and fib. 1069-1074, 2008.

[3] Uchida Y., Takeyama T. and Dei T., "Ultra high strength fiber reinforced concrete using aramid fiber," Proceedings of Fracture Mechanics of Concrete and Concrete Structures - High Performance, Fiber Reinforced Concrete, Special Loadings and Structural Applications, 14921494, 2010.

[4] Baba S. et al., "Fire Resistance of Pre-Stressed Slabs in Ultra High Performance Concrete for Use in an Office Building Retrofit Project," Proceedings of the 8th International Symposium on Utilization of High-Strength and High-performance Concrete, CD-ROM, 2008.

[5] Ozawa M., Morimoto H., "High-Strength Concrete Reinforced Jute Fiber and Water-Soluble PVA Fiber under High Temperature," Proceedings of the Sixth International Conference on Structures in Fire, 864-871, 2010.

[6] Heo, Y. S., Sanjayan, J. G., Han, C. G., Han, M. C., "Synergistic effect of combined fibers for spalling protection of concrete in fire," Cement and Concrete Research 40,1547-1554, 2010.

[7] M. Ozawa, Z. Bo, Y. Uchida, H. Morimoto:Preventive Effects of Different Types of Fibers on UFC Spalling at High Temperatures, Proceedings of 7th International Conference on Structures in Fire, M. Fontana, A. Frangi, M. Knobloch (Eds.), 747-755, 2012.6. 